\title{
Prognostic Value of Ejection Fraction in Patients Admitted with Non-ST-Segment Elevatin Myocardial Infarction
}

\author{
VERO NICA GHEORMAN ${ }^{1}$, VENERA CRISTINA DINESCU ${ }^{2}$, MICHAEL SCHENKER ${ }^{3}$, DENISE RAMONA MALIN ${ }^{4}$, \\ MIOARA DESDEMONA STEPAN 5 , OANA CRICIOTOIU 6 , DIANA STANCA ${ }^{6}$, ADRIAN MITA7 , SORIN NICOLAE DINESCU ${ }^{8 *}$, \\ ELENA CATALINA BICA ${ }^{5}$, MARIUS BICA ${ }^{9}$, MANUELA IULIANA DRAGOMIR ${ }^{10}$, FLORIN MARIUS ROMANESCU ${ }^{11}$, \\ RAZVAN COSMIN PANA ${ }^{12}$, VICTOR GHEORMAN ${ }^{13}$ \\ University of Medicine and Pharmacy of Craiova, Cardiology Department, 2 Petru Rares Str., 200349, Craiova, Romania \\ 2University of Medicine and Pharmacy of Craiova, Health Promotion and Ocupational Medicine Department, 2 Petru Rares Str., \\ 200349, Craiova, Romania \\ 3University of Medicine and Pharmacy of Craiova, Oncology Department, 2 Petru Rares Str., 200349, Craiova, Romania \\ ${ }^{4}$ University of Medicine and Pharmacy of Craiova, Otorhinolaryngology Department, 99 Calea Bucuresti Str., 200473, Craiova, \\ Romania \\ 5University of Medicine and Pharmacy of Craiova, Department of Pediatrics, 2 Petru Rares Str., 200349, Craiova, Romania \\ UUniversity of Medicine and Pharmacy of Craiova, Neurology Department, Neuropsychiatry Hospital of Craiova, 99 Calea \\ Bucuresti Str., 200473, Craiova, Romania \\ ZUniversity of Medicine and Pharmacy of Craiova, Internal Medicine Department, Filantropia Hospital of Craiova, 1 Filantropiei \\ Str., 200143, Craiova, Romania \\ ¿University of Medicine and Pharmacy of Craiova, Epidemiology and Primary Health Care Department, 2 Petru Rares Str., 200349, \\ Craiova, Romania \\ University of Medicine and Pharmacy of Craiova, Surgery Department, 2 Petru Rares Str.,200349, Craiova, Romania \\ ${ }^{10}$ University of Medicine and Pharmacy of Craiova, Department of Public Health and Healthcare Management, 2 Petru Rares \\ Str.,200349, Craiova, Romania \\ ${ }^{11}$ University of Medicine and Pharmacy of Craiova, Department of Physiology, 2 Petru Rares Str.,200349, Craiova, Romania \\ ${ }^{12}$ University of Medicine and Pharmacy of Craiova, Department of Obstetrics and Gynecology, 2 Petru Rares Str.,200349, Craiova, \\ Romania \\ ${ }^{13}$ University of Medicine and Pharmacy of Craiova, Psychiatry Department, Neuropsychiatry Hospital of Craiova, 24 Aleea Potelu \\ Str., 200473, Craiova, Romania
}

Despite the progress in correcting cardiovascular risk factors and pharmacological and interventional therapy, acute myocardial infarction continues to be a major cause of mortality and morbidity worldwide.In literature exist limited information about the factors that affect the outcomes of acute myocardial infarction at patients with a different degree of left ventricular dysfunction. Our aim was to identify the factors associated with LV ejection fraction (LVEF) at first admission to patients with non-ST-segment elevation myocardial infarction.

Key words: left ventricle ejection fraction, non-ST-segment elevation myocardial infarction, risk assessment

Echocardiography represents the imaging method of choice for assessing ventricular function in patients with clinical cardiac disease [1-6]. The multiple advantages are: echocardiography in emergency conditions, at hemodynamically unstable patients, it has good accuracy and is noninvasive and provides decisive information for diagnosis, risk stratification, therapeutic decision and follow-up of treatment effects.

Assessment of left ventricular function is an essential component of the echocardiographic examination. According to the literature, the assessment of the left ventricle global systolic function through the ejection fraction (LVEF) allows the differentiation of patients in three categories: patients with LVEF preserve (e" $50 \%$ ), patients with reduced LVEF (typically d" 40\%) and patients with intermediate FEVS (40-50\%) [1]. This classification may suggest particularities related to the ventricular dysfunction substrate, comorbidities, demographic findings, and therapy response of patients with non-ST-segment elevation myocardial infarction.

The left ventricular ejection fraction is the most commonly used parameter in assessing the systolic function of the left ventricle. It is calculated by dividing the beating volume to the telediastolic volume of the left ventricle: LVEF $=($ VTDLV - VTSLV) / VTDLV x 100. As well it is recommended to measure volumes by $2 \mathrm{D}$ echocardiography using the modified Simpson method or monoplan elipsoid. For the patients with a difficult echographic window, ultrasound with contrast will be used for a better endocardial view [7-11].

The diagnosis of acute coronary syndromes without ST segment elevation is established based on the presence of angina pectoris of a character different than stable angina pectoris in the absence of persistent ST segment elevation on the electrocardiogram.

The documentation of myocardial ischemia by increasing cardiac biomarkers, the emergence of new left ventricular parietal kinetics, the evidence of unstable atherosclerotic lesions in the coronary arteries are elements that support the diagnosis.

\section{Experimental part}

The aim of the study

In our study, we included patients admitted to the County Hospital of Craiova, Cardiology Department, between January 2018 and January 2018. The main criterion in our study was the certain diagnosis of non-ST-segment 
elevation myocardial infarction, which was based on the clinical examination, laboratory findings, electrocardiography data and echocardiography.

The echocardiographic examination was performed during the firstday of the hospitalization, and the estimated ejection fraction was interpreted and reported by experienced cardiologists in echocardiography. All the examination was performed according to European guidelines.

The main objective of our study was to evaluate the ejection fraction of left ventricle at patients with non-STsegment elevation myocardial infarction at admission and to correlate the prognostic consequence of its value.

\section{Results and discussions}

The left ventricular ejection fraction (LVEF) had an average of $42.51 \pm 10.45(95 \% \mathrm{Cl} 41.28$ - 43.74) and the distribution of non-ST-segment elevation myocardial infarction cases identified more than half of the patients with LVEF of $30-49 \%$ ( $\mathrm{N}=155,55.4 \%) .24$ cases showed severe ejection fraction ( $8.6 \%$ ) and only 101 of cases (36.1 \%) with LVEF was found to be over 50\% (fig.1).

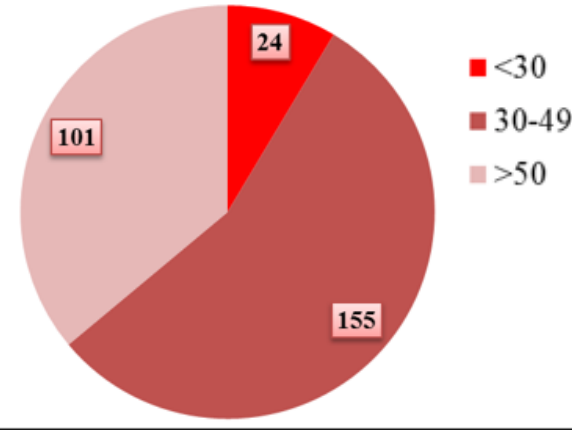

Fig. 1.
The age of patients with LVEF under $50 \%$ was 70 years of age and older, for those with LVEF below 30\% (71.86 \pm 10.25 years) and those with LVEF between $30-49 \%$ (70.25 \pm 11.99 years) and under 70 years in those with a reasonable ejection fraction of over 50\% (69.22 \pm 11.91 years). A significant deterioration of FEVS with age may occur (Table 1).

Although statistically insignificant $(p=0.38)$, males were more severely affected by impairment of $L V E F$, almost $10 \%(9.6 \%, N=15)$ had LVEF below $30 \%$ compared with women $(7,3 \%, N=9)$, and those with LVEF major than $49 \%$ were less $(32.7 \%, N=51)$ than women $(40.3 \%, N=$ 50).

In contrast, mean LVEF values were significantly higher $(p=0.0199)$ in females $(44.14 \pm 10.26)$ compared with males ( $41.22 \pm 10.45)$, indicating more severe impairment of LVEF in males.

Although high BMI values had a predisposition to obesity for the NSTEMI patients from our lot, the LVEF values below $30 \%$ were more than $50 \%$ higher $(p=0.16)$ in obese patients of $10.6 \%(\mathrm{~N}=7)$ compared to those without obesity $6.4 \%(\mathrm{~N}=8)$, the impact of obesity on impairment to LVEF being know [13].

Nearly a quarter of the NSTEMI cases from our lot were exposed to smoking, to them LVEF below $30 \%$ were nearly $50 \%$ more $(9.5 \%, \mathrm{~N}=7)$ than those patients from out lot not exposed to smoking $6.5 \%(\mathrm{~N}=13)$.

The prevalence of HBP was $85.1 \%$, this risk factor being probably one of the most severe risk factors associated with the non-ST-segment elevation myocardial infarction.

The impact of HBP on LVEF was significant, almost 18\% of HBP cases from our lot presented LVEF below $30 \%$ ( $N=$

\begin{tabular}{|c|c|c|c|c|c|}
\hline & $\%(\mathrm{~N})$ & $\begin{array}{c}\text { LVEF }<30 \% \\
(\mathrm{~N}=\mathbf{2 4})\end{array}$ & $\begin{array}{l}\text { LVEF 30-49\% } \\
\text { (N=155) }\end{array}$ & $\begin{array}{c}\text { LVEF }>49 \% \\
(\mathrm{~N}=101)\end{array}$ & $\mathbf{P}$ \\
\hline Age & $( \pm \mathrm{SD})^{\mathrm{b}}$ & $7186 \pm 10.25$ & $70.25 \pm 11,99$ & $69.22 \pm 11,91$ & 0.001 \\
\hline \multirow{2}{*}{ Gender } & Male & $9.6(15)$ & $57.7(90)$ & $32.7(51)$ & \multirow{2}{*}{0.3848} \\
\hline & Female & $7.3(9)$ & $52.4(65)$ & $40.3(50)$ & \\
\hline \multirow[b]{2}{*}{ Smoking } & Smoker & $9.5(7)$ & $55.4(41)$ & $35.1(26)$ & \multirow[b]{2}{*}{0.4285} \\
\hline & $\begin{array}{l}\text { Non } \\
\text { Smoker }\end{array}$ & $6.5(13)$ & $56.0(112)$ & $37.5(75)$ & \\
\hline \multirow{2}{*}{ Obesity } & Positive & $10.3(16)$ & $58.1(90)$ & $31.6(49)$ & \multirow{2}{*}{0.164} \\
\hline & Without & $6.4(8)$ & $52.0(65)$ & $41.6(52)$ & \\
\hline \multirow{2}{*}{ History of stroke } & Positive & $13.6(16)$ & $62.7(74)$ & $23.7(28)$ & \multirow{2}{*}{$<0.001$} \\
\hline & Without & $4.9(8)$ & $50.0(81)$ & $45.1(73)$ & \\
\hline \multirow{2}{*}{$\begin{array}{l}\text { Percutaneous } \\
\text { coronary } \\
\text { intervention }\end{array}$} & Positive & $11.8(6)$ & $52.9(27)$ & $35.3(18)$ & \multirow{2}{*}{0.054} \\
\hline & Without & $7.9(18)$ & $55.9(128)$ & $36.2(83)$ & \\
\hline \multirow{2}{*}{$\begin{array}{l}\text { High blood } \\
\text { pressure }\end{array}$} & Positive & $17.9(40)$ & $48.7(108)$ & $33.3(74)$ & \multirow{2}{*}{$<0.001$} \\
\hline & Without & $7.7(3)$ & $56.4(22)$ & $35.9(14)$ & \\
\hline \multirow{2}{*}{ Diabetes mellitus } & Positive & $11.1(10)$ & $57.8(52)$ & $31.1(28)$ & \multirow{2}{*}{0.085} \\
\hline & Without & $7.4(14)$ & $54.2(54.2 \%)$ & $38.4(75)$ & \\
\hline \multirow{2}{*}{$\begin{array}{l}\text { Congestive heart } \\
\text { failure }\end{array}$} & Positive & $13.0(21)$ & $63.6(103)$ & $23.5(38)$ & \multirow{2}{*}{$<0.001$} \\
\hline & Without & $2.6(3)$ & $44.0(51)$ & $53.4(62)$ & \\
\hline \multirow{2}{*}{ Cerebral stroke } & Positive & $8.3(3)$ & $58.3(21)$ & $33.3(12)$ & \multirow{2}{*}{0.925} \\
\hline & Without & $8.6(21)$ & $54.9(134)$ & $36.5 \%(89)$ & \\
\hline \multirow[t]{2}{*}{ Stent implantation } & Positive & $15.8(3)$ & $52.6(10)$ & $31.6(6)$ & \\
\hline & Without & $8.0(21)$ & $55.6(145)$ & $36.4(95)$ & 0.027 \\
\hline cTni & $( \pm \mathrm{SD})^{2}$ & $0.855 \pm 1.4$ & $2.26 \pm 1.98$ & $1.351=3.45$ & \\
\hline $\begin{array}{l}\text { Days of } \\
\text { hospitalization }\end{array}$ & $( \pm \mathrm{SD})^{6}$ & $9.42 \pm 5.14$ & $8.43 \pm 4.27$ & $7.26 \pm 3.47$ & $<0.001$ \\
\hline
\end{tabular}

Table 1 
40) as opposed to HBP-free cases from our study where LVEF under $30 \%$ was identified in only 7 cases $(7.7 \%)$.

For patients with high blood pressure from out study, the risk of LVEF impairment below $30 \%$ was more than 2 times higher than in non-HBP patients. $(\mathrm{RR}=2.22,95 \% \mathrm{Cl}=$ 1.01-4.94, $P=0.0496$ ).

In our study, patients with LVEF less than $30 \%$ were almost 3 times more often $(13.6 \%, \mathrm{~N}=16)$ than in nonstroke cases $(4.9 \%, N=8)$, and we observed a low presence of LVEF cases over $50 \%$ in only 29 patients (23.7\%) vs. 73 patients (45.1\%) without history of stroke. In this context, the risk of LVEF impairment to less than $30 \%$ was 2.19 times higher in cases of patients with stroke $(\mathrm{RR}=2.19,95 \% \mathrm{Cl} 1.08-5.41, \mathrm{P}=0.0398)$.

The history of coronary heart disease as a risk factor for LVEF impairment is also supported by the higher incidence of LVEF cases below $30 \%$ in those with a personal history of coronarography $(11.8 \%, \mathrm{~N}=6)$ compared to those with no previous coronarographies $(7.9 \%, N=18)$, as well as the presence of a stent implantation associated with a double prevalence ( $p=0.027$ ) of patients with LVEF $<30 \%$ $(15.8 \%, N=3)$ compared to patients without a history of percutaneous coronary intervention without stent implantation $(8 \%, \mathrm{~N}=21)$.

The LVEF decreased more than $30 \%$ was five times more frequent $(p<0.001)$ in NSTEMI patients with congestive heart failure associated $(13.6 \%, \mathrm{~N}=21)$ compared to non-congestive heart failure cases $(2.4 \%, \mathrm{~N}$ $=3$ ), the risk of LVEF impairment less than $30 \%$ was more than 3 times higher in CHF-associated cases of patients with NSTEMI from our lot, than those patients without CHF $(\mathrm{RR}=3.39,95 \% \mathrm{Cl} 1.051-10.911, \mathrm{p}=0,041)$. Moreover, maintaining a LVEF of over $50 \%$ was over two times lower in NSTEMI patients associating CHF $(23.5 \%, \mathrm{~N}=38)$ compared to those without $\operatorname{CHF}(53.4 \%, \mathrm{~N}=62)$.

The mean days of hospitalization required to manage NSTEMI patients with an LVEF below 30\% (9.42 \pm 5.14 days) were greater with 2 days $(p=0.015)$ and one day ( $p$ $=0.09$ ) for those with the left ventricular ejection fraction of $30-49 \%$ ( $8.43 \pm 4.27$ days ) compared to those with the LVEF over $50 \%$ ( $7.26 \pm 3.47$ days) .

\section{Conclusions}

Our results show that LVEF is a strong predictor of mortality and should be considered a part of early routine assessment and stratification of risk in patients with myocardial infarction.

\section{Abbreviations \\ NSTEMI: non-ST-segment elevation myocardial infarction \\ LVEF : left ventricular ejection fraction \\ BMI: body mass index \\ HBP: high blood pressure \\ CHF: congestive heart failure}

\section{References}

1. PONIKOWSKI P et al. 2016 ESC Guidelines for the diagnosis and treatment of acute and chronic heart failure: The Task Force for the diagnosis and treatment of acute and chronic heart failure of the European Society of Cardiology (ESC). Developed with the special contribution of the Heart Failure Association (HFA) of the ESC. Eur J Heart Fail. 2016 Aug; 18(8):891-975.
2. OSIAC E., BALSEANU T-A., CATALIN B. et al. Optical coherence tomography as a promising imaging tool for brain investigations. Romanian Jurnal of Morphology and Embriology. Volume 55 Issue 2, Supplement:S.2014. Pages 507-512.

3. DINESCU, V.C., PUIU, I., DINESCU, S.N., TUDORASCU, D.N., BICA, E.C., VASILE, R.C., BUNESCU, M.G., ROMANESCU, F.M., CIOATERA, N., ROTARU, L.T., MUSTAFA, E.R., FLORESCU, F. Early Predictive Biochemical Electrocardiographic and Echocardiographic Markers for Cardiac Damage in Patients with Pulmonic Silicosis. Rev Chim (Bucharest), 70, no.1, 2019, p.63-68.

4.CALBOREAN, V., GHEORMAN, V.,CONSTANTIN, C. ISTRATOAIE, O., Venous Thromboembolism Secondary to Adult-Onset Still's Disease: a Case Report, Journal of Cardiovascular Emergencies, 2018, 4, $\mathrm{nr} .2, \mathrm{p} .101-105$.

5.CALBOREAN, V. GHEORMAN, V., DINESCU, S.N., STANCA, D.,GALCEAVA, O.,. FORTOFOIU, M., MITA, A., MIHAILOVICI, A.R., MISCOCl, S.A., BALEANU, V.D., DINESCU, V.C., Arrhythmia Risk in Patients with Chronic Hepatic Disease. Rev. Chim (Bucharest) 69, no. 11, 2018, p. 4237-4240.

6.CALBOREAN, V., CIOBANU, D., MIREA, S.C., GALCEAVA, O.,GHEORMAN, V., PADUREANU, V., FORTOFOIU, C.M., FORTOFOIU,M., MITA, A., DINESCU, S.N., MISCOCI, S.A., DINESCU, V.C. Benefit of Cardiac Resynchronization Therapy in Patients with Heart Failure. Rev. Chim. (Bucharest), 69, no. 9, 2018, p.2461-2464.

7. LANG RM etal. Recommendations for cardiac chamber quantification by echocardiography in adults: an update from the American Society of Echocardiography and the European Association of Cardiovascular Imaging. Eur Heart J Cardiovasc Imaging. 2015 Mar; 16(3):233-70

8. PUIU, I., DAN, A.O., TARTEA, E.A., ROGOVEANU, O.C., BICA, E.A., DINESCU, S.N., VASILE, R.C., DINESCU, V.C., ROMANESCU, F.M., TUDORASCU, D.R., Assessing Factors that influence the Level of Glycated Hemoglobin in Children and Adolescents with Type 1 Diabetes. Rev. Chim. (Bucharest), 69, no. 11, 2018, p.4233-4236.

9.ENE, C.G., ROSU, A., GHEORMAN, V., CALBOREAN, V., TENEA COJ AN, T.S., ROGOVEANU, O.C., VLADU, M.I., RADU, L., Incidence of Osteoporosis and the Risk of Fracture in Patients with Rheumatoid Arthritis Undergoing Corticosteroid Treatment, Rev. Chim. (Bucharest), 69, no. 7, 2018, p.1851-1854.

10. CALBOREAN, V., GHEORMAN, V., AL NAMAT, R., CAZACU, I.M., VARJU, P., GEDE, N., STREBA, T.C., VERE, C.C., GHEONEA, D.I., GHEORMAN, V., LUNGULESCU, C., LUNGULESCU, C., V. The Association Between Stress Level and Laboratory Parameters, Sex,Age and Stage Disease in Patients with Digestive and Bronchopulmonary Neoplasms, Rev. Chim. (Bucharest), 68, no 12, 2017, p.3010-3014.

11.VLADU, I.M., RADU, L., GIRGAVU, S.R., TENEA COJAN, T.S., ENE, C.G., CALBOREAN, V., GHEORMAN, V., CLENCIU, D. Alteration of Glucidic Metabolism in Relation with Visceral Adiposity Index, Rev Chim (Bucharest), 69,no 9, 2018, p.2479-2481.

12.GHEORMAN, V., DINESCU, V.C., CRICIOTOIU, O., STANCA, D., CALBOREAN, V., MITA, A. MISCOCI, A., DAVITOIU, D.V., BALEANU, V.D., NEDELCUTA, R.M., DINESCU, S.N., DIJ MARESCU, A.L., VOICULESCU, D.I., UDRISTOIU, I., Clinical and Biochemical Changes Induced by Alcoholat the Patients with Mental Illness. Rev. Chim. (Bucharest), 70, no. 4, 2019, p.1406-1410.

13. BUETTNER H.J., MUELLER C., GICK M, FERENC M, ALLGEIER J, COMBERG T, WERNER K.D., SCHINDLER C., AND NEUMANN F.J. The impact of obesity on mortality in UA/non-STsegment elevation myocardial infarction; European Heart J ournal (2007) 28, 1694-1701.

Manuscript received:12.11.2018 